\title{
Clinical Profile and the Role of Rapid Serological Tests: Typhifast IgM and Enterocheck WB in the Diagnosis of Typhoid Fever
}

\author{
Rahul J Bhume ${ }^{1}$, Prakash Babaliche ${ }^{2}$
}

\begin{abstract}
Introduction: During identification and diagnosis, typhoid fever (TF) causes various issues such as nonspecific symptoms and nontyphoidal Salmonella-associated febrile diseases. Accurate identification and diagnosis are still a substantial concern. The current study was undertaken to study the clinical profile of TF and the role of Typhifast IgM and Enterocheck WB in early diagnosis.

Materials and methods: Clinically suspected TF patients (121) were included in the study. Patients with antibiotic history during the period of febrile illness were excluded. The diagnosis was confirmed with blood culture test. Widal test and two new rapid serological tests: Typhifast lgM and Enterocheck WB were performed. The outcomes were compared with blood culture-confirmed cases to derive the sensitivity and specificity of the diagnostic tests. The clinical characteristics were compared with diagnostic tests using Chi-square test.

Results: The most common presentations of TF were fever, chills, vomiting, abdominal pain, anorexia, constipation, and diarrhea. Among the 121 clinically suspected TF patients, 67 had positive blood culture tests for Salmonella typhi. The Typhifast IgM and Enterocheck WB showed sensitivity of $97.01 \%$ and $68.52 \%$, respectively. Specificity was also more with Typhifast IgM (85.07\%) than with Enterocheck WB (62.96\%). When tests were used in parallel combination, $97.01 \%$ sensitivity was attained, while the specificity dropped to $46.30 \%$. When used in serial combination, sensitivity of $85.07 \%$ and specificity of $85.19 \%$ were observed.

Conclusion: Stepladder fever, abnormal serum glutamic oxaloacetic transaminase (SGOT), and abnormal albumin are associated with blood culture, Typhifast IgM, and Enterocheck WB tests. Rapid serological tests might assist in accurate and early identification of TF.

Keywords: Blood culture, Enterocheck WB, Salmonella enterica serotype typhi, Typhifast IgM, Widal test.

Indian Journal of Critical Care Medicine (2020): 10.5005/jp-journals-10071-23417
\end{abstract}

\section{INTRODUCTION}

Enteric fever or typhoid fever (TF) is one of the substantial life-threatening illnesses observed predominantly in the developing countries. ${ }^{1}$ In 2010, approximately 12 million cases were encountered with clinically determined TF, and globally, around 0.13 million TF-related mortalities occur every year. ${ }^{2}$ Probable contributing factors for disease incidence include high population density, underprivileged and impoverished areas, inadequate sanitization, unavailability of pure drinking water, and low socioeconomic status. ${ }^{2}$ Typhoid fever is caused by Salmonella enterica serovars such as Typhi and Paratyphi A, B, and C. ${ }^{1}$ The Salmonella species are transmitted through the consumption of food and water that are contaminated with fecal matter-excreting pathogenic bacteria. Entry of Salmonella through fecal-oral route invades the gastrointestinal epithelium, thereby migrating to the gut mucosa and spreads systemically throughout the body via the bloodstream. ${ }^{3}$ Classical clinical manifestations include high temperature, which can rise up to $38-40^{\circ} \mathrm{C}$, chills, abdominal discomfort, and hepatosplenomegaly. ${ }^{4}$ Diagnosis of TF by isolation of Salmonella species from the bloodstream and treatment with appropriate antibiotics are the significant methods for timely management of TF. ${ }^{5}$

Although the disease and its complications are known from the 19th century, ${ }^{6}$ the burden of TF remains the same. The predominant reason for such drawback indicates the lack of suitable diagnostic tools and the emergence of drug-resistant strains. ${ }^{5}$ Blood, bone marrow, and fecal cultures are considered as the most reliable
1,2 Department of Medicine, Jawaharlal Nehru Medical College, Belagavi, Karnataka, India

Corresponding Author: Prakash Babaliche, Department of Medicine, Jawaharlal Nehru Medical College, Belagavi, Karnataka, India, e-mail: kle.publications@gmail.com

How to cite this article: Bhume RJ, Babaliche P. Clinical Profile and the Role of Rapid Serological Tests: Typhifast IgM and Enterocheck WB in the Diagnosis of Typhoid Fever. Indian J Crit Care Med 2020;24(5): 307-312.

Source of support: Nil

Conflict of interest: None

diagnostic tools. ${ }^{7}$ Cultures provide definitive evidence of the infection and the information regarding the antibiotic sensitivity of the isolate. ${ }^{8}$ Sensitivity of blood culture varies from $40 \%$ to $60 \%$ and bone marrow culture varies between $55 \%$ and $67 \% .{ }^{9}$ Sensitivity and specificity of the bone marrow culture are superior to fecal and blood cultures; however, due to its invasive nature, the procedure is not frequently used. Moreover, blood culture sensitivity depends on various factors such as the volume considered for culture, degree of disease progression, bacterial load in the sample, and self-treatment with antimicrobials. ${ }^{10}$

Contemporary research recommends the culture tests along with the serological techniques for the early diagnosis of TF. In the developing countries, the equipment required for blood culture

(c) The Author(s). 2020 Open Access This article is distributed under the terms of the Creative Commons Attribution 4.0 International License (https://creativecommons. org/licenses/by-nc/4.0/), which permits unrestricted use, distribution, and non-commercial reproduction in any medium, provided you give appropriate credit to the original author(s) and the source, provide a link to the Creative Commons license, and indicate if changes were made. The Creative Commons Public Domain Dedication waiver (http://creativecommons.org/publicdomain/zero/1.0/) applies to the data made available in this article, unless otherwise stated. 
are significantly deficient, especially in the nonurban areas, due to which the clinicians depend only on serological diagnostic tools. In most developing countries, Widal test is an extensively employed serological tool, which detects the antibodies against the $S$. enterica ser. Typhi " $\mathrm{O}$ " and " $\mathrm{H}$ " antigens; however, its sensitivity and specificity are significantly poor and the predictive values vary between the geographical regions. Studies on the use of Widal test have reported misdiagnosis and inappropriate treatment of TF, which limit its employment. ${ }^{11}$ Novel rapid serological tests such as Typhifast IgM and Enterocheck WB detect IgM or IgG antibodies to several purified antigens of the pathogen. Typhifast IgM and Enterocheck WB are rapid, simple, and affordable tests; however, few studies are available in the literature that derive the efficacy of these rapid serological tests. Considering the facts and several issues raised regarding the diagnosis and treatment of TF, the current study was undertaken to evaluate the clinical profile of TF and to analyze the role of rapid serological tests-Typhifast IgM and Enterocheck WB-individually and in combination in the early detection of TF.

\section{Materials and Methods}

The present cross-sectional study was conducted in the department of medicine, from January to December 2014. A total of 121 patients with clinical features suggestive of TF such as fever, headache, and abdominal discomfort were included in the study. Patients aged between 12 and 65 years, irrespective of the gender, with $\geq 5$ days of fever were included in the study. Patients receiving antibiotics during the period of febrile illness were excluded from the study. Ethical clearance was obtained from Institutional Ethics Committee. Before the commencement of the study, written informed consent was obtained from the patients.

\section{Data Collection}

Patients were interviewed regarding the demographic data such as age, gender, occupation, and history of similar complaints and treatment for the same. Patients were subjected to a thorough physical examination, including pulse rate, blood pressure, respiratory rate, and other clinical signs and symptoms of TF such as fever, abdominal discomfort, and constipation. Systemic examinations such as complete blood count, liver function test, Widal test, blood culture, urine routine and microscopy, Typhifast IgM, and Enterocheck WB were also conducted.

\section{Widal Test}

Blood serum sample was serially diluted with $0.86 \%$ saline solution. Standard $\mathrm{O}$ and $\mathrm{H}$ antigens were prepared, added to the tubes, and were incubated for 60 minutes at $37^{\circ} \mathrm{C}$. The tubes were centrifuged for around 5 minutes and observed for agglutination. Widal test titer $\geq 1: 160$ was considered as the optimal cutoff titer value to detect TF in our study population. ${ }^{11,12}$

\section{Blood Culture}

Blood culture was performed to isolate the organism according to the standard procedures followed using the BacT $\backslash$ ALERT 3D automated system (bioMerieux, France). ${ }^{13}$ Any isolated bacterium was identified using Vitek II (bioMerieux, France) identification system and the presence of the same was confirmed by slide-agglutination test with particular antisera (Remel Europe Ltd., UK).

\section{Typhifast lgM}

Typhifast IgM (AB Diagnopath Manufacturing Pvt. Ltd., New Delhi) is a commercially available serological kit based on dotenzyme-immunoassay that specifically detects the presence of IgM antibodies triggered against the somatic, flagellar, or capsular antigens of Salmonella subspecies S. enterica ser. Typhi. ${ }^{14}$ Typhifast lgM uses immunochromatography phenomenon for the detection; and the assay was performed according to the manufacturer instructions. ${ }^{15}$ Volume of about $10 \mu \mathrm{L}$ of serum or plasma sample and $20 \mu \mathrm{L}$ of whole blood were added to the square well I, followed by addition of one drop of chase buffer. On the well II, three drops of chase buffer were added, and plastic tap was pulled. Results were interpreted after 10 minutes and the overall assay time required was 15 minutes.

\section{Interpretation}

Appearance of color bands with any intensity at the test line as well as on the control line was represented as positive for typhoidspecific lgM antibodies. The presence of colored band only at the control line were represented as negative for typhoid-specific IgM antibodies, and it was considered invalid if the control line was absent.

\section{Enterocheck WB}

Enterocheck WB is a rapid sandwich immunoassay, which functions on the principle of immunochromatography. It specifically detects the antibodies triggered against the lipopolysaccharide of the pathogen in the human serum. ${ }^{16}$ Detection of the pathogen by Enterocheck WB was performed using the commercially available kit (Zephyr Biomedicals, Goa, India). The test was performed by adding $5 \mu \mathrm{L}$ of serum sample on port " $\mathrm{A}$ " and five drops of running buffer on port " $B$ ". The overall time required for the assay was 15 minutes.

\section{Interpretation}

In positive samples, the serum IgM forms conjugates with anti-lgM colloid gold, which flows further along the membrane to the test line establishing a pink-purple colored band. In negative samples, only the rabbit IgG complex flows along the membrane to the control line, establishing a pink-purple colored band.

\section{Statistical Analysis}

Data were analyzed using Microsoft excel spreadsheet. Parameters such as clinical manifestations of TF were compared with blood culture, Typhifast IgM, and Enterocheck WB and the comparison was performed using Chi-square test. The continuous data were expressed as mean \pm standard deviation (SD). The sensitivity and specificity of the serological tests were determined individually and in combination using MedCalc software.

\section{Results}

Among the study population (121), male preponderance (81) was observed and male to female ratio was 2.02:1. Mean age was 31.70 \pm 15.08 years. All (121) patients presented with fever, whereas 14 patients had stepladder pattern of fever, which was once considered as the hallmark of TF. Chills and abdominal pain were observed in 62 and 38 patients, respectively. Few patients (41) presented with atypical symptoms such as altered sensorium, burning micturition, hematemesis, melena, and sore throat.

On evaluation of blood culture, 67 patients confirmed Salmonella enterica ser. Typhi isolation; of these, 37 patients tested 
positive for Widal test. The sensitivity of Widal test was $55.22 \%$ and specificity was $74.04 \%$. Positive and negative predictive values of Widal test were $72.55 \%$ and $57.14 \%$. Among the study population, 51 patients tested positive for Widal test.

Clinical complications such as stepladder fever, serum glutamic oxalo-acetic transaminase (SGOT), and albumin were significantly associated with blood culture, Typhifast IgM, and Enterocheck WB. Abnormal erythrocyte sedimentation rate was associated with blood culture $(p<0.015)$ and Enterocheck WB $(p<0.001)$. Total protein was associated with Typhifast IgM $(p<0.003)$ and Enterocheck WB $(p<0.001)$. Chills $(p<0.012)$, myalgia $(p<0.050)$, and constipation $(p<0.049)$ were significantly associated with blood culture (Table 1). Eosinophil count $(p<0.045)$ was associated with Typhifast IgM (Table 2$)$. History of TF $(p<0.049)$, coated tongue $(p<0.008)$, and direct bilirubin $(<0.009)$ were associated with Enterocheck WB (Table 3).

Among the 121 patients, 67 were blood culture-positive and 82 were Typhifast IgM positive. Of the 67 blood culture-positive patients, 65 were positive for Typhifast lgM. The sensitivity and specificity of Typhifast IgM, with blood culture as the reference standard, were $97.01 \%$ and $68.52 \%$, respectively. The positive and negative predictive values were $79.27 \%$ and $94.87 \%$, respectively (Table 4).

Among the 67 blood culture-positive patients, 57 were positive for Enterocheck WB. The sensitivity and specificity of Enterocheck WB, with blood culture as the reference standard, were $85.07 \%$ and $62.96 \%$. The positive and negative predictive values were $74.03 \%$ and $77.27 \%$, respectively (Table 4 ).

Global sensitivity and specificity of Typhifast IgM and Enterocheck WB, when performed in series, were $85.07 \%$ and $85.19 \%$, respectively. When performed in parallel, sensitivity was $97.01 \%$, whereas specificity was $46.30 \%$ (Table 4 ).

\section{Discussion}

Typhoidal Salmonella infections are bloodstream infections, which bear complexity in distinguishing the various other nontyphoidal Salmonella-associated febrile diseases; thereby, interfering in the interpretation of the serological tests. ${ }^{17}$ Management of TF using standard drugs such as chloramphenicol, ampicillin, and trimethoprim-sulfamethoxazole changed with the emergence of multidrug-resistant strains. ${ }^{18}$ In the current study, most of the patients were in the age-group of 21-30 years and the mean age was 31.70 years. The probable reasons behind the highest prevalence in this age-group include mobility, consumption of unhygienic food and water, and age-group illiteracy. These observations were consistent with various other studies. ${ }^{19,20}$ Clinical manifestations that are believed as the typical presentations of TF such as slow stepladder fever pattern and toxicity are becoming rare due to the development of multidrug resistance. The nonspecific manifestations due to multidrug resistance contribute to inaccurate diagnosis and improper management. ${ }^{21}$ This inconsistency forces clinicians to depend specifically on the serological diagnostics.

Clinical manifestation varies from mild illness with groundlevel fever to severe complications such as abdominal pain, hepatosplenomegaly, and anorexia. In the current study, all clinically suspected typhoid patients presented with fever; however, the stepladder fever pattern, which was once the hallmark of TF, was observed in $11.57 \%$ patients. Salmonella enterica serotypes are acid-tolerant organisms, which can survive in the gastric acid and successfully establish the infection in the gut mucosa causing
Table 1: Association between blood culture test and different clinical characteristics

\begin{tabular}{|c|c|c|c|c|}
\hline \multirow{2}{*}{\multicolumn{2}{|c|}{ Clinical characteristics }} & \multicolumn{2}{|c|}{ Blood culture } & \multirow[b]{2}{*}{$p$ value } \\
\hline & & \multirow{2}{*}{$\begin{array}{l}\text { Positive } \\
(n=67) \\
14\end{array}$} & \multirow{2}{*}{$\begin{array}{c}\text { Negative } \\
(n=54)\end{array}$} & \\
\hline \multirow{14}{*}{$\begin{array}{l}\text { History of } \\
\text { symptoms }\end{array}$} & Stepladder fever & & & $0.0001^{*}$ \\
\hline & Chills & 27 & 35 & $0.012^{*}$ \\
\hline & Cough & 16 & 7 & 0.197 \\
\hline & Sweating & 4 & 1 & 0.501 \\
\hline & Myalgia & 10 & 17 & $0.050^{*}$ \\
\hline & Malaise & 9 & 6 & 0.914 \\
\hline & Arthralgia & 4 & 2 & 0.881 \\
\hline & Anorexia & 22 & 11 & 0.185 \\
\hline & Abdominal pain & 22 & 16 & 0.856 \\
\hline & Nausea and vomiting & 22 & 25 & 0.186 \\
\hline & Diarrhea & 11 & 3 & 0.116 \\
\hline & Constipation & 13 & 3 & $0.049^{*}$ \\
\hline & Others & 24 & 23 & 0.567 \\
\hline & History of typhoid & 6 & 4 & 1.00 \\
\hline \multirow{8}{*}{$\begin{array}{l}\text { General } \\
\text { physical } \\
\text { examination }\end{array}$} & Pallor & 11 & 17 & 0.082 \\
\hline & Icterus & 7 & 7 & 0.885 \\
\hline & Coated tongue & 21 & 11 & 0.248 \\
\hline & Rash & 4 & 2 & 0.881 \\
\hline & Relative bradycardia & 9 & 2 & 0.125 \\
\hline & Toxemia & 13 & 4 & 0.104 \\
\hline & Abnormal pulse rate & 21 & 12 & 0.360 \\
\hline & $\begin{array}{l}\text { Abnormal respiratory } \\
\text { rate }\end{array}$ & 30 & 20 & 0.500 \\
\hline \multirow[t]{9}{*}{$\mathrm{CBC}$} & Abnormal systolic BP & 15 & 9 & 0.578 \\
\hline & Low hemoglobin & 43 & 39 & 0.456 \\
\hline & $\begin{array}{l}\text { Abnormal platelet } \\
\text { count }\end{array}$ & 14 & 17 & 0.264 \\
\hline & Abnormal TC & 26 & 31 & 0.063 \\
\hline & $\begin{array}{l}\text { Abnormal neutrophil } \\
\text { count }\end{array}$ & 23 & 15 & 0.565 \\
\hline & $\begin{array}{l}\text { Abnormal lymphocyte } \\
\text { count }\end{array}$ & 28 & 23 & 1.00 \\
\hline & $\begin{array}{l}\text { Abnormal eosinophil } \\
\text { count }\end{array}$ & 20 & 11 & 0.328 \\
\hline & $\begin{array}{l}\text { Abnormal monocyte } \\
\text { count }\end{array}$ & 10 & 12 & 0.425 \\
\hline & Abnormal ESR & 59 & 37 & $0.015^{*}$ \\
\hline \multirow[t]{7}{*}{ LFT } & Abnormal total bilirubin & 5 & 1 & 0.321 \\
\hline & $\begin{array}{l}\text { Abnormal direct } \\
\text { bilirubin }\end{array}$ & 27 & 27 & 0.377 \\
\hline & Abnormal SGOT & 47 & 27 & $0.038^{*}$ \\
\hline & Abnormal SGPT & 40 & 38 & 0.304 \\
\hline & Abnormal AKP & 30 & 26 & 0.852 \\
\hline & Abnormal total protein & 32 & 19 & 0.227 \\
\hline & Abnormal albumin & 39 & 16 & $0.003^{*}$ \\
\hline
\end{tabular}

\footnotetext{
*Significant, $p<0.05$.
}

CBC, complete blood count; BP, blood pressure; LFT, liver function test; TC, total count; ESR, erythrocyte sedimentation rate; SGOT, serum glutamic oxaloacetic transaminase; SGPT, serum glutamic-pyruvate transaminase; AKP, alkaline phosphatase 
Table 2: Association between Typhifast IgM test and different clinical characteristics

\begin{tabular}{|c|c|c|c|c|}
\hline & & \multicolumn{2}{|c|}{ Typhifast IgM } & \multirow[b]{2}{*}{$p$ value } \\
\hline \multicolumn{2}{|c|}{ Clinical characteristics } & $\begin{array}{l}\text { Positive } \\
(n=82)\end{array}$ & $\begin{array}{l}\text { Negative } \\
(n=39)\end{array}$ & \\
\hline \multirow{14}{*}{$\begin{array}{l}\text { History of } \\
\text { symptoms }\end{array}$} & Stepladder fever & 14 & 0 & $0.014^{*}$ \\
\hline & Chills & 38 & 24 & 0.108 \\
\hline & Cough & 16 & 7 & 1 \\
\hline & Sweating & 5 & 0 & 0.277 \\
\hline & Myalgia & 19 & 8 & 0.924 \\
\hline & Malaise & 11 & 4 & 0.843 \\
\hline & Arthralgia & 4 & 2 & 1 \\
\hline & Anorexia & 26 & 7 & 0.170 \\
\hline & Abdominal pain & 25 & 13 & 0.915 \\
\hline & Nausea and vomiting & 30 & 17 & 0.589 \\
\hline & Diarrhea & 13 & 1 & 0.0669 \\
\hline & Constipation & 14 & 2 & 0.127 \\
\hline & Others & 26 & 17 & 0.283 \\
\hline & History of typhoid fever & 5 & 5 & 0.367 \\
\hline \multirow{8}{*}{$\begin{array}{l}\text { General } \\
\text { physical } \\
\text { examination }\end{array}$} & Pallor & 17 & 11 & 0.496 \\
\hline & Icterus & 9 & 5 & 1 \\
\hline & Coated tongue & 25 & 7 & 0.214 \\
\hline & Rash & 4 & 2 & 1 \\
\hline & Relative bradycardia & 10 & 1 & 0.166 \\
\hline & Toxemia & 13 & 4 & 0.583 \\
\hline & Abnormal pulse rate & 23 & 10 & 0.952 \\
\hline & $\begin{array}{l}\text { Abnormal respiratory } \\
\text { rate }\end{array}$ & 36 & 14 & 0.523 \\
\hline \multirow[t]{9}{*}{ CBC } & Abnormal systolic BP & 16 & 8 & 1 \\
\hline & Low hemoglobin & 51 & 31 & 0.090 \\
\hline & $\begin{array}{l}\text { Abnormal platelet } \\
\text { count }\end{array}$ & 19 & 15 & 0.125 \\
\hline & Abnormal TC & 34 & 23 & 0.107 \\
\hline & $\begin{array}{l}\text { Abnormal neutrophil } \\
\text { count }\end{array}$ & 27 & 11 & 0.753 \\
\hline & $\begin{array}{l}\text { Abnormal lymphocyte } \\
\text { count }\end{array}$ & 37 & 14 & 0.445 \\
\hline & $\begin{array}{l}\text { Abnormal eosinophil } \\
\text { count }\end{array}$ & 26 & 5 & $0.045^{*}$ \\
\hline & $\begin{array}{l}\text { Abnormal monocyte } \\
\text { count }\end{array}$ & 21 & 10 & 1 \\
\hline & Abnormal ESR & 19 & 9 & 1 \\
\hline \multirow[t]{7}{*}{ LFT } & $\begin{array}{l}\text { Abnormal total } \\
\text { bilirubin }\end{array}$ & 5 & 1 & 0.697 \\
\hline & $\begin{array}{l}\text { Abnormal direct } \\
\text { bilirubin }\end{array}$ & 33 & 21 & 0.225 \\
\hline & Abnormal SGOT & 57 & 17 & $0.011^{*}$ \\
\hline & Abnormal SGPT & 49 & 29 & 0.172 \\
\hline & Abnormal AKP & 35 & 21 & 0.339 \\
\hline & Abnormal total protein & 39 & 7 & $0.003^{*}$ \\
\hline & Abnormal albumin & 46 & 3 & $<0.001^{*}$ \\
\hline
\end{tabular}

*Significant, $p<0.05$.

CBC, complete blood count; BP, blood pressure; LFT, liver function test; TC, total count; ESR, erythrocyte sedimentation rate; SGOT, serum glutamic oxaloacetic transaminase; SGPT, serum glutamic-pyruvate transaminase; AKP, alkaline phosphatase
Table 3: Association between Enterocheck WB and different clinical characteristics

\begin{tabular}{|c|c|c|c|c|}
\hline \multirow{2}{*}{\multicolumn{2}{|c|}{ Clinical characteristics }} & \multicolumn{2}{|c|}{ Enterocheck } & \multirow[b]{2}{*}{ pvalue } \\
\hline & & $\begin{array}{l}\text { Positive } \\
(n=77)\end{array}$ & $\begin{array}{l}\text { Negative } \\
(n=44)\end{array}$ & \\
\hline \multirow{14}{*}{$\begin{array}{l}\text { History of } \\
\text { symptoms }\end{array}$} & Stepladder fever & 13 & 1 & $0.033^{*}$ \\
\hline & Chills & 35 & 27 & 0.134 \\
\hline & Cough & 16 & 7 & 0.677 \\
\hline & Sweating & 5 & 0 & 0.210 \\
\hline & Myalgia & 15 & 12 & 0.445 \\
\hline & Malaise & 11 & 4 & 0.584 \\
\hline & Arthralgia & 4 & 2 & 1.000 \\
\hline & Anorexia & 22 & 11 & 0.832 \\
\hline & Abdominal pain & 19 & 19 & 0.056 \\
\hline & Nausea and vomiting & 28 & 19 & 0.584 \\
\hline & Diarrhea & 11 & 3 & 0.347 \\
\hline & Constipation & 14 & 2 & 0.064 \\
\hline & Others & 25 & 18 & 0.461 \\
\hline & History of typhoid fever & 3 & 7 & $0.049 *$ \\
\hline \multirow{8}{*}{$\begin{array}{l}\text { General } \\
\text { physical } \\
\text { examination }\end{array}$} & Pallor & 14 & 14 & 0.137 \\
\hline & Icterus & 11 & 3 & 0.347 \\
\hline & Coated tongue & 27 & 5 & $0.008^{*}$ \\
\hline & Rash & 5 & 1 & 0.552 \\
\hline & Relative bradycardia & 10 & 1 & 0.100 \\
\hline & Toxemia & 11 & 6 & 1.000 \\
\hline & Abnormal pulse rate & 22 & 11 & 0.832 \\
\hline & $\begin{array}{l}\text { Abnormal respiratory } \\
\text { rate }\end{array}$ & 33 & 17 & 0.793 \\
\hline \multirow[t]{9}{*}{$\mathrm{CBC}$} & Abnormal systolic BP & 17 & 7 & 0.560 \\
\hline & Low hemoglobin & 50 & 32 & 0.496 \\
\hline & $\begin{array}{l}\text { Abnormal platelet } \\
\text { count }\end{array}$ & 19 & 15 & 0.369 \\
\hline & Abnormal TC & 37 & 20 & 0.931 \\
\hline & $\begin{array}{l}\text { Abnormal neutrophil } \\
\text { count }\end{array}$ & 20 & 18 & 0.133 \\
\hline & $\begin{array}{l}\text { Abnormal lymphocyte } \\
\text { count }\end{array}$ & 31 & 20 & 0.714 \\
\hline & $\begin{array}{l}\text { Abnormal eosinophil } \\
\text { count }\end{array}$ & 23 & 8 & 0.23 \\
\hline & $\begin{array}{l}\text { Abnormal monocyte } \\
\text { count }\end{array}$ & 10 & 12 & 0.086 \\
\hline & Abnormal ESR & 63 & 10 & $<0.001^{*}$ \\
\hline \multirow[t]{7}{*}{ LFT } & $\begin{array}{l}\text { Abnormal total } \\
\text { bilirubin }\end{array}$ & 5 & 1 & 0.552 \\
\hline & $\begin{array}{l}\text { Abnormal direct } \\
\text { bilirubin }\end{array}$ & 27 & 27 & $0.009 *$ \\
\hline & Abnormal SGOT & 54 & 20 & $0.012^{*}$ \\
\hline & Abnormal SGPT & 47 & 31 & 0.398 \\
\hline & Abnormal AKP & 35 & 21 & 0.958 \\
\hline & Abnormal total protein & 9 & 17 & $0.001 *$ \\
\hline & Abnormal albumin & 7 & 20 & $<0.001^{*}$ \\
\hline
\end{tabular}

*Significant, $p<0.05$

CBC, complete blood count; BP, blood pressure; LFT, liver function test; TC, total count; ESR, erythrocyte sedimentation rate; SGOT, serum glutamic oxaloacetic transaminase; SGPT, serum glutamic-pyruvate transaminase; AKP, alkaline phosphatase 
Clinical Profile and Diagnosis of Typhoid

Table 4: Sensitivity and specificity of Typhifast lgM and Enterocheck WB, individually and combined in series and parallel

\begin{tabular}{lllll}
\hline & Typhifast IgM (\%) & Enterocheck WB (\%) & Series (\%) & Parallel (\%) \\
\hline Sensitivity & $97.01(89.63-99.64)$ & $85.07(74.26-92.60)$ & $85.07(74.26-92.60)$ & $97.01(89.63-99.64)$ \\
Specificity & $68.52(54.45-80.48)$ & $62.96(48.74-75.71)$ & $85.19(72.88-93.38)$ & $46.30(32.62-60.39)$ \\
PPV & $79.27(72.02-85.03)$ & $74.03(66.49-80.36)$ & $87.69(78.86-93.16)$ & $69.15(63.55-74.24)$ \\
NPV & $94.87(82.36-98.65)$ & $77.27(64.94-86.19)$ & $82.14(71.98-89.17)$ & $92.59(75.60-98.06)$ \\
\hline
\end{tabular}

PPV, positive predictive value; NPV, negative predictive value

abdominal discomfort. ${ }^{17}$ In the current study, gastrointestinal symptoms such as diarrhea, abdominal pain, and constipation were found prominent among the study population. This suggests that the presence of fever and gastrointestinal discomfort might assist the clinicians in suspecting the presence of TF complications.

Current study found that clinical feature, such as stepladder fever, was present significantly in both Typhifast IgM and Enterocheck WB as well as in blood culture-positive patients. Although the blood culture represented significant results for abdominal complications such as constipation, both Typhifast IgM and Enterocheck WB showed no significance toward abdominal complications. Liver function tests showed that among Typhifast IgM- and Enterocheck WB-positive patients including blood culture-positive patients, the presence of abnormal SGOT and abnormal albumin values was significantly observed. These findings suggest that along with stepladder fever and abdominal pain, the impaired liver function may invariably predict the development of TF. Histopathological study of liver showed the presence of typhoid nodules, swelling, and mononuclear cell infiltrate in focal regions, and liver biopsy culture showed the presence of bacilli in the parenchyma cells. ${ }^{22}$ Furthermore, studies reported that TF can contribute to increased levels of aminotransferase and development of jaundice, which leads to hepatic impairment. ${ }^{23}$

Widal test is a widely employed serological test in the developing countries, which detects the specific agglutinating antibodies that are released against the lipopolysaccharide $(O)$ and flagella $(\mathrm{H})$ antigens of the pathogen. Widal test requires increasing titer of paired samples after 10-14 days; however, in the case of TF and blood culture-confirmed TF cases such fourfold rise is not demonstrable. ${ }^{7}$ Results of Widal tests need careful interpretation, considering the history of vaccination and Salmonella-associated infections. Main drawback of Widal tests is cross-reactivity for non-Salmonella infections such as malaria, dengue, and brucellosis in TF-endemic regions. ${ }^{24}$ Various studies reported the poor predictive results and controversial specificity and sensitivity for Widal tests. ${ }^{11,25}$ In the current study, Widal test titer $\geq 1: 160$ was the optimal cutoff titer value of TF. In a study by Andualem et al., ${ }^{7}$ the sensitivity and specificity were $71.4 \%$ and $68.44 \%$, respectively, in Widal test-positive titer in relation to blood culture-confirmed cases; positive and negative predictive values were $5.7 \%$ and $98.9 \%$, respectively. The above findings suggest that Widal test neither has good sensitivity nor specificity and that relying only on Widal test in the diagnosis of TF may be misleading.

Typhifast IgM is one of the commercially available kit which works on Typhidot IgM principle. Due to the lack of literature on the studies conducted on Typhifast, the current study considered Typhidot IgM for comparison, as it employs similar working principle. Sensitivity and specificity of Typhidot vary between $70-100 \%$ and $43-90 \% .{ }^{8,26}$ In a study conducted by Krishna et al., ${ }^{26}$ the sensitivity and specificity of the Typhidot IgM were $100 \%$ and $95.5 \%$, respectively, in comparison to blood culture. The positive and negative predictive values were $89.2 \%$ and $100 \%$, respectively. The findings of the current study were in concordance with the findings of the above study. ${ }^{26}$

A study by Anusha et al. ${ }^{16}$ reported the sensitivity and specificity of Enterocheck, in relation to blood culture, were $85.5 \%$ and $88.6 \%$, respectively; and the negative and positive predictive values were $97.7 \%$ and $51.1 \%$, respectively. Typhifast IgM appears to be a more sensitive and specific test with a high negative predictive value. Sensitivity and specificity variations may exist between the tests due to the cross-reactivity of the outer membrane protein antigens of different organisms such as S. enterica ser. Typhi and S. enterica ser. Paratyphi $A$.

To our knowledge, this is the first study that used a combination of serological tests for improving the diagnosis of TF. Typhifast IgM and Enterocheck were performed in series as well as in parallel for evaluating its effectiveness, surprisingly, the study discovered that sensitivity as well as the specificity was improved when executed both in series along with better positive (74.03\%) and negative predictive values (77.27\%), respectively. In parallel testing, sensitivity was $97 \%$; however, specificity and the positive predictive values were relatively reduced when compared to individual and series tests. Hence, the diagnosis can be improved with the use of a combined serological testing approach.

Current study findings conclude that both the rapid serological tests, Typhifast IgM and Enterocheck WB, offer increased sensitivity and specificity than Widal test, and even better results when employed both in combination. Both render rapidity, early diagnosis, and simplicity than blood culture and can replace the most extensively used serological test-Widal test. However, the current findings should be enriched with larger sample size and longer follow-up. Moreover, in highly suspected cases of TF, clinical management should not depend on the negative results of the serological tests.

\section{Conclusion}

In the current study, clinical features such as step ladder fever, abdominal pain, vomiting, diarrhea, and constipation were associated with the diagnosis of TF. It was observed that stepladder fever, abnormal SGOT, and abnormal albumin were present significantly in both Typhifast IgM and Enterocheck WB as well as in blood culture-positive patients. Typhifast IgM and Enterocheck WB showed promising results with good sensitivity and specificity when compared with blood culture. Rapid serological diagnostic tests, either as individual tests or in combination, are necessary in the early diagnosis of TF; however, confirmation with culture techniques is mandatory.

\section{References}

1. Bhutta ZA. Current concepts in the diagnosis and treatment of typhoid fever. BMJ 2006;333(7558):78-82. DOI: 10.1136/bmj.333.7558.78. 
2. John J, Van Aart CJ, Grassly NC. The burden of typhoid and paratyphoid in India: Systematic review and meta-analysis. PLoS Negl Trop Dis 2016;10(4):e0004616. DOI: 10.1371/journal.pntd.0004616.

3. Näsström E, Jonsson P, Johansson A, Dongol S, Karkey A, Basnyat B, et al. Diagnostic metabolite biomarkers of chronic typhoid carriage. PLoS Negl Trop Dis 2018;12(1):e0006215. DOI: 10.1371/journal. pntd.0006215.

4. Buckle GC, Walker CL, Black RE. Typhoid fever and paratyphoid fever: Systematic review to estimate global morbidity and mortality for 2010. J Glob Health 2012;2(1):010401. DOI: 10.7189/jogh.02.010401.

5. Amicizia D, Arata L, Zangrillo F, Panatto D, Gasparini R. Overview of the impact of typhoid and paratyphoid fever. Utility of ty21a Vaccine (vivotif(r)). J Prev Med Hyg 2017;58(1):E1-E8.

6. Marineli F, Tsoucalas G, Karamanou M, Androutsos G. Mary mallon (1869-1938) and the history of typhoid fever. Ann Gastroenterol 2013;26(2):132-134.

7. Andualem G, Abebe T, Kebede N, Gebre-Selassie S, Mihret A, Alemayehu H. A comparative study of widal test with blood culture in the diagnosis of typhoid fever in febrile patients. BMC Res Notes 2014;7(1):653. DOI: 10.1186/1756-0500-7-653.

8. Siba V, Horwood PF, Vanuga K, Wapling J, Sehuko R, Siba PM, et al. Evaluation of serological diagnostic tests for typhoid fever in papua new guinea using a composite reference standard. Clin Vaccine Immunol 2012;19(11):1833-1837. DOI: 10.1128/CVI.00380-12.

9. Mogasale V, Ramani E, Mogasale VV, Park J. What proportion of Salmonella typhi cases are detected by blood culture? A systematic literature review. Ann Clin Microbiol Antimicrob 2016;15(1):32. DOI: 10.1186/s12941-016-0147-z.

10. Moore CE, Pan-Ngum W, Wijedoru LPM, Sona S, Nga TVT, Duy PT, et al. Evaluation of the diagnostic accuracy of a typhoid IgM flow assay for the diagnosis of typhoid fever in cambodian children using a bayesian latent class model assuming an imperfect gold standard. Am J Trop Med Hyg 2014;90(1):114-120. DOI: 10.4269/ajtmh.13-0384.

11. Wasihun AG, Wlekidan LN, Gebremariam SA, Welderufael AL, Muthupandian S, Haile TD, et al. Diagnosis and treatment of typhoid fever and associated prevailing drug resistance in northern ethiopia. Int J Infect Dis 2015;35:96-102. DOI: 10.1016/j.ijid.2015.04.014.

12. Kinikar Anagha BD, Shahriar R, Sanjeev K. The easy and early diagnosis of typhoid fever. J Clin Diagn Res Title 2012;6:198-199.

13. Lee DH, Kim SC, Bae IG, Koh EH, Kim S. Clinical evaluation of bact/ alert fa plus and fn plus bottles compared with standard bottles. J Clin Microbiol 2013;51(12):4150-4155. DOI: 10.1128/JCM.01935-13.
14. Gasem MH, Smits HL, Goris MG, Dolmans WM. Evaluation of a simple and rapid dipstick assay for the diagnosis of typhoid fever in indonesia. J Med Microbiol 2002;51(2):173-177. DOI: 10.1099/00221317-51-2-173.

15. Ltd. ADMP. For rapid detection of acute typhoid fever: India Mart; 2010 [cited 2015]. Available from: https://www.indiamart.com/ abdiagnopathmanufacturing/detailing.html.

16. Anusha R, Ganesh R, Lalitha J. Comparison of a rapid commercial test, enterocheck wb((r)), with automated blood culture for diagnosis of typhoid fever. Ann Trop Paediatr 2011;31(3):231-234. DOI: 10.1179/1465328111Y.0000000030.

17. Crump JA, Sjolund-Karlsson M, Gordon MA, Parry CM. Epidemiology, clinical presentation, laboratory diagnosis, antimicrobial resistance, and antimicrobial management of invasive salmonella infections. Clin Microbiol Rev 2015;28(4):901-937. DOI: 10.1128/CMR.00002-15.

18. Bhutta ZA, Naqvi SH, Razzaq RA, Farooqui BJ. Multidrug-resistant typhoid in children: presentation and clinical features. Rev Infect Dis 1991;13(5):832-836. DOI: 10.1093/clinids/13.5.832.

19. Talwar S, Sharma RK, Mittal DK, Prasad P. Typhoid enteric perforation. Aust N Z J Surg 1997;67(6):351-353. DOI: 10.1111/j.1445-2197.1997. tb01990.x.

20. Sharvani R, Hemavathi, Dayanand DK, Shenoy P, Sarmah P. Antibiogram of Salmonella isolates: time to consider antibiotic salvage. J Clin Diagn Res 2016;10:DC06-DC08.

21. Dutta TK, Beeresha, Ghotekar LH. Atypical manifestations of typhoid fever. J Postgrad Med 2001;47:248-251.

22. Karoli R, Fatima J, Chandra A, Singh G. Salmonella hepatitis: An uncommon complication of a common disease. J Family Med Prim Care 2012;1(2):160-162. DOI: 10.4103/2249-4863.104992.

23. Minemura $M$, Tajiri K, Shimizu Y. Liver involvement in systemic infection. World J Hepatol 2014;6(9):632-642. DOI: 10.4254/wjh. v6.i9.632.

24. Wijedoru L, Mallett S, Parry CM. Rapid diagnostic tests for typhoid and paratyphoid (enteric) fever. Cochrane Database Syst Rev 2017;5:CD008892. DOI: 10.1002/14651858.CD008892.pub2.

25. Adhikari A, Rauniyar R, Raut PP, Manandhar KD, Gupta BP. Evaluation of sensitivity and specificity of ELISA against Widal test for typhoid diagnosis in endemic population of Kathmandu. BMC Infect Dis 2015;15(1):523. DOI: 10.1186/s12879-015-1248-6.

26. Krishna S, Desai S, Anjana V, Paranthaaman R. Typhidot (IgM) as a reliable and rapid diagnostic test for typhoid fever. Ann Trop Med Public Health 2011;4(1):42-44. DOI: 10.4103/1755-6783.80535. 